\title{
Development News in Print Media of Pakistan: The Case of Urdu and English Press
}

\author{
* Dr. Babar Hussain Shah, Lecturer \\ ** Dr. Malik Adnan, Assistant Professor (Corresponding Author) \\ *** Dr. Irem Sultana, Assistant Professor
}

\begin{abstract}
This research was aimed to explore the coverage of development related news in Pakistani print media. To analyze the coverage, two leading newspapers of Pakistan-daily Dawn and daily Jang were selected by the researchers. Both are leading newspapers of Urdu and English language. The study is based on content analysis with a purposive sampling technique. All development news appearing on front, back and inner pages of newspapers were analyzed. The period for selection of news was from November $1^{\text {st, }} 2018$ to December $31^{\text {st }} 2018$. In this study, all those news are unit of analysis which deal with the core issue of development in any form. Results indicate that during that period overall 572 news stories appeared in newspapers out of which 271 appeared in Urdu newspapers and 301 appeared in English newspapers. It was explored that most published news was about the infrastructure category of development (20.09\%). It was also revealed that the least number of stories (2.75\%) appeared on the front pages of the newspapers. It was found that overall $9.09 \%$ news stories were accompanied by images. Results indicate that the English press provided more space to development news than Urdu newspapers.
\end{abstract}

Keywords: Development, Press, News, Coverage, Pakistan.

Introduction

The advent of new technologies and rapidly spreading media have provided a greater impetus to the development. In the development and excellence of any nation, the role of media has greater importance. It is the power of media that can make and break and even can construct the image of a nation (Kelleher, C. D. 2014). Communication is an integral part of our daily lives and it can play an important and effective role in the development process of a society. The developing nations of the world are in a continuous struggle to achieve a state of self-sufficiency and independence. They try to adopt different strategies to fulfill their needs. These needs are social, moral, political, and material. The developing nations struggle to break the shackles of poverty, mismanagement, bad governance and illiteracy is decade long (Hussain, T. 2017). In the current age of technology and information development is inevitable. As a result of rapid changes in life, people want to keep themselves updated with all the developments happening in the society. They have different desires to feel and keep themselves accomplished, and media in this context can serve as a vehicle to satisfy those needs. If we look at the change from the development perspective it will be more evident in our life. Change and development are interlinked and media have also their share to disseminate development in all segments of the society (Hujanen, J. 2013).

So it is quite clear that communication can be used as an effective tool for undertaking development activities and also disseminating output of the development in any society. There are two ends in the development process, one is the development planners like government or agencies and the other end is of receivers or masses, who are the beneficiaries of these development programs. Media work as a bridge between these two ends and the success of this process lies in the strength of, how well both ends are connected.

\section{Statement of the Problem}

Mass media is an important source of information dissemination and along with it also plays its role in the formation of public opinion. So far as the landscape of Pakistan media is concerned it ranges from print to electronic media. Besides the above media types, social media has also emerged an important

* Department of Mass Communication, Allama Iqbal Open University, Islamabad
** Department of Media Studies, The Islamia University of Bahawalpur
Email: dr.adnan@iub.edu.pk
*** Department of Mass Communication, Government College University, Faisalabad 
tool of information. It is important to know the role of print media in the provision of coverage of development news. This study has also been designed to examine the extent of coverage print media provides development with the following objectives.

- To explore the extent of coverage provided to development news in newspapers.

- To know about the different categories of development mentioned in the newspapers.

- To know about the placement of development news on different pages of the newspapers.

\section{Research Questions}

1. What was the extent of coverage provided to different categories of development news by leading newspapers of Pakistan?

2. Which Pakistani newspaper provided more coverage to development news?

3. What was the placement of development news on different pages of the newspapers?

4. How many news items were accompanied by a pictorial image?

\section{Literature Review}

Singhal \& Rogers (2001) describe development as a participatory process that is directed towards social change by bringing social and material development in the lives of the majority of the people and enabling the people to gain control of their environment. It can be inferred that development encompassed all spheres of life. In the process of development, journalists have an important role to play by informing them about the happenings of the society. Development journalism results in providing soul to media it gives as it accords a human face to the profession. Development journalism enables the general public to understand the development goals of their implication and their benefits. While journalism is considered as one of the important instruments for national development, however, there is a controversy between Eastern and Western media professionals regarding practices of development journalism. According to West coverage of development in East is greatly dependent upon the official sources so the coverage in the newspapers is usually tailored to support the government and its policies. The result is that coverage of development has a high correlation with the activities and image building of political figures and most news stories promote government and its policies; especially in Asian countries. We do not want to indulge in controversy but we have to analyze that how much content related to development appears in the Pakistani press. It is further to opine that for third world countries development journalism is far more important than in developed countries as these are the countries which are striving for development, though developed nations at once must secure the status of developed ones. However, it is well understood that development journalism can play an effective, important, and vital role in achieving change both at the individual and societal level. Perrottet, A. J. D. (2015) is of the view that in some of the countries development communication is confused with the publicity of the different projects undertaken by the respective governments. He believes that media serves as a vehicle to promote plans of development undertaken by the government according to the aspirations of administrators. But development communication is not merely this rather it goes beyond. It is also important to note that in many developing countries like Asian and African, the government tries to intervene and try to control media by applying whatever rules and regulations. Shah, (1990) stated that it is usually observed that government-owned media is used by the respective governments in their favor. In most cases, government officials are seen as the main source of information as in media routines normally a larger space is devoted to the quotes of influential and powerful political elites while covering development news. He is of the view that with the further strengthening of democracy, privatization of media industry on market based economy and freedom of the press can further guarantee in the selection of news contents for development journalism. As a result of this frequent free voices can be heard across the country and development journalism can be flourished at a rapid pace. It is the dilemma of poor countries that journalists usually associate them with some political groups for their survival but in doing so they are prone to the threat of losing their impartiality and independence. In third world countries, development journalism gains more importance as the journalists in these regions view news media as an important instrument or tool of development which helps in achieving both social justice and beneficial social change. In other words, media is expected to publish development tasks in a positive way that is in line with the nationally established policies. McDaniel (1986) explains that political leaders in developing countries desire to be seen as real heroes behind all sorts of development in the country. It is quite obvious that developing countries are seemed to be heavily dependent to adopt development journalism as numerous development issues and changes are taking place in these 
countries and media is serving as a tool of dissemination of development news in these countries.Oladele (2009) stated that in many developing countries media are vehicles carrying and disseminating information about economic, social, cultural, and technological aspects and political changes in the developing countries. They further view that respective governments in these countries see media as opportunities to exercise their power through the practice of development journalism. The study of Hussain, T. \& Shabir, G. (2019) was designed to investigate the treatment of developmental issues in Indian and Pakistani print media. They concluded that overall news coverage of development matters remained less in published news items, prominent placement, and space. Though the ratio of development matters remained favorable and the results of the study showed that the attention is not being given to the development issues in Pakistani as well as in the Indian press.

Theoretical Framework

The study is conducted under the base of development theory as this theory provides the baseline to develop journalism researches.

\section{Research Design}

The study is based on content analysis and a purposive sampling technique is applied to collect the relevant data. Two newspapers; daily Jang and daily Dawn have been selected. Both newspapers are leading newspapers of Urdu and English language in Pakistan. The criterion for their selection was that both of the newspapers belonged to a leading newsgroup and as well both of them enjoy the highest circulation in Urdu and English across Pakistan. In this study, all those news are unit of analysis which deal with the core issue of development in any form. The period for selection of news is from November 1st, 2018 to December 31st, 2018.

\section{Content Categorization}

The following categories of development news will be analyzed while studying the contents of the sample newspapers.

i. Economic news: All those news that deal with economic development will be considered as economic news.

ii. Education: News dealing with news in any form will fall under the category of education

iii. Health: All news items that cover health-related matters or issues will be counted as health

iv. Environment: Those news items dealing with the environment will be counted as the development category of the environment.

v. Women Empowerment: The news items that include news about empowering women in society will be regarded as women empowerment.

vi. Children Rights protection: Those news items which include items about children and protection of their rights will be considered as children right protection.

vii. Infrastructure: News items that deal with physical infrastructure in the form of building constructions, dams, etc. will be counted as infrastructure.

viii. Agriculture development: Those news items that deal with agriculture will fall under the category of agricultural development.

ix. Energy: All news items that deal with energy in any form by its solar, Sydal, or any energy from will be considered in the umbrella of energy.

x. Industrial development: News items dealing with any type of industry and its flourishing will be considered items related to industrial development.

xi. Miscellaneous: Those news items that fall under the umbrella of development but are not mentioned in the above categories will be categorized as miscellaneous.

Data Analysis

To draw the comparison between the Urdu newspaper-Daily Jang and English newspaper- Daily Dawn, the two months newspaper from $1^{\text {st }}$ November 2018 to $31^{\text {st }}$ December 2018 were analyzed. The theme under which the data was analyzed restricted to development news only. The analysis paid attention to placement, length of the news, and pictorial presentation of the stories.

Table 1: Overall Coverage of Development Issues

\begin{tabular}{lcc}
\multicolumn{1}{c}{ Content Categories } & News Published (Frequency) & Percentage \\
\hline Education & 77 & 13.5 \\
Health & 58 & 10.1 \\
Economy & 92 & 16 \\
Environment & 21 & 3.6 \\
\hline
\end{tabular}




\begin{tabular}{lcc}
\hline Women Empowerment & 29 & 5 \\
Children Rights & 6 & 1 \\
Infrastructure & 115 & 20.17 \\
Agriculture & 20 & 3.49 \\
Energy & 52 & 9 \\
Industrial Development & 15 & 2.62 \\
Miscellaneous/Others & 87 & 15.2 \\
Total & 572 & 100 \\
\hline
\end{tabular}

According to the results of the above table 1, it is quite evident that newspapers published different news about development which includes different categories of development. It can be found that the major proportion of development issue was about infrastructure (20.17 percent) and a second number there was news about miscellaneous/other categories of development (15.2 percent). There was a great proportion of news about education (13.5 percent). The least number of new included were about children rights; only (1 percent.).

Table 2: Categories wise Coverage in Newspapers

\begin{tabular}{lllllll}
\hline & \multicolumn{7}{l}{ Frequency } & \multicolumn{2}{l}{$\begin{array}{l}\text { AVERAGE LENGTH } \\
\text { (centimeters) }\end{array}$} & Pictures & \\
\hline News Categories & JANG & DAWN & JANG & DAWN & JANG & DAWN \\
Education & 40 & 37 & 12.8 & 32 & 1 & 5 \\
Health & 20 & 38 & 12.8 & 30.6 & 0 & 2 \\
Economic & 45 & 47 & 20.7 & 25.1 & 3 & 5 \\
Environment & 8 & 13 & 8.4 & 37.3 & 0 & 0 \\
Women employment & 6 & 23 & 11.2 & 35 & 0 & 2 \\
Children rights & 3 & 3 & 31 & 30 & 0 & 0 \\
Infrastructure & 60 & 55 & 15.5 & 29.8 & 3 & 14 \\
Agriculture & 7 & 13 & 11.1 & 24.8 & 0 & 1 \\
Energy & 31 & 21 & 19.2 & 27.2 & 1 & 2 \\
Industrial dev & 6 & 9 & 13.7 & 30 & 2 & 0 \\
Misc. /others & 45 & 42 & 13.8 & 35.9 & 4 & 7 \\
Total & 271 & 301 & 170.2 & 337.7 & 14 & 38 \\
\hline
\end{tabular}

Table 2 provides a comprehensive picture of all categories of development and their coverage concerning their frequencies and space covered in sample newspapers. According to the table, the highest number of stories were covered by daily Jang with 60 stories followed by Dawn with 55 stories about infrastructure. At second number Miscellaneous/ others category was published in Daily Jang and Daily Dawn; with Jang having 45 stories and Daily Dawn 42. Thirdly there were news stories about Education with Daily Jang 40 and Daily Dawn 37 stories. Overall Daily Dawn published more news (301) about development as compared with Daily Jang (271).

The average length of the stories was measured in terms of centimeters. According to Table 2 overall average length of news stories about development was larger in Daily Dawn (337.7 centimeter) than Daily Jang (170.2 centimeter). When average length about categories of development was analyzed it was found that news stories about the environment occupied more space in Daily Dawn with an average length of 37.3 centimeters. At the second number, the length was greater about the miscellaneous category of development in Dail Dawn having a length of 35.9 centimeters. Results from the table very clearly indicates that English newspaper- Daily Dawn has stories with higher length than do the Urdu newspaper, Daily Jang. During data analysis researcher also searched for various pictures that were published about the different categories of development in sample newspapers. A significant difference was observed between Daily Dawn and Daily Jang about the publication of pictures. It was observed that Daily Dawn (38 pictures) published more pictures than Daily Jang (14 pictures). It can be seen that the largest number of pictures were published by Daily Dawn (14 pictures) and these pictures were also related to the infrastructure category of development. On second number there were 7 pictures about miscellaneous/another category of development published by Daily 


\section{Diagram 3: Placement of News on Front, Middle, and Last Page}

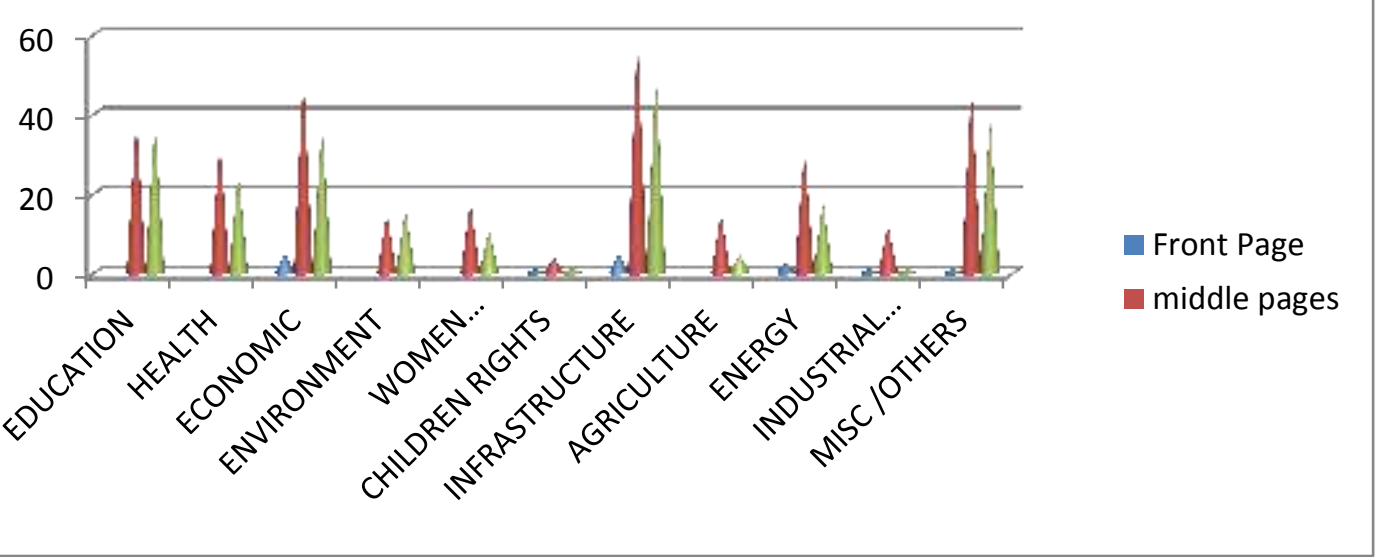

Diagram 3 elaborates on the total number of stories the newspapers and their placement on the front, back, and inner pages. The above diagram indicates that most of the stories that appeared on the front pages were about infrastructure.

\section{Diagram 4: Overall Placement of News in Newspapers}

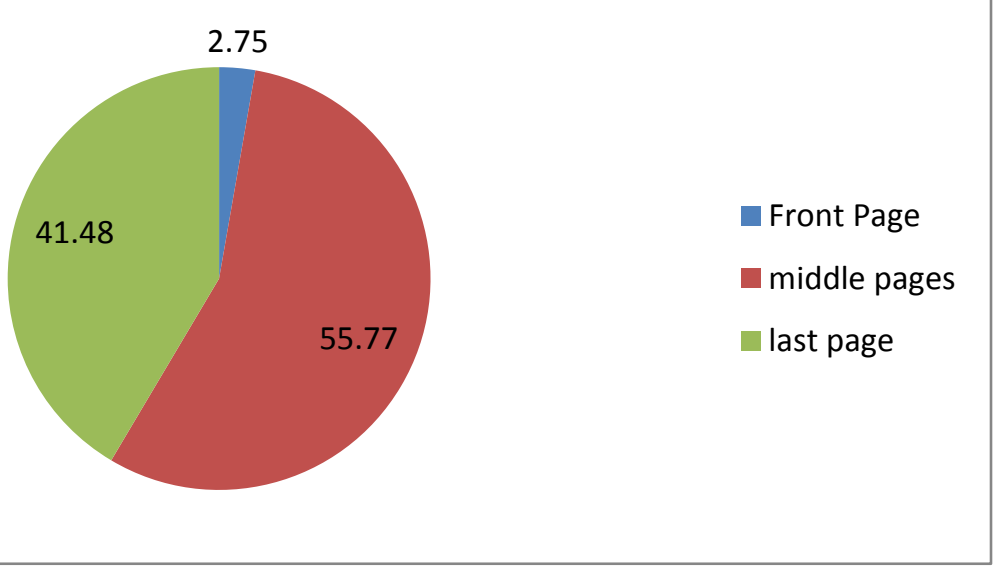

As per diagram -4 , the above mention graphical representation out of total 572 development news only $2.75 \%$ news was provided the front page, $55.77 \%$ was given coverage in middle pages whereas the remaining $41.48 \%$ coverage was provided in the last pages. Accordingly, very little coverage was given to development news in front pages of the newspapers. Most of the stories in the newspapers were carried in the inside page or middle page. This shows that the attention given to the development issue was substantially less.

The number of stories published in the Daily Dawn and Daily Jang newspaper respectively, on the front page, middle pages, and on the last pages also indicates the editorial mindset of the newspapers and their priorities in the field of development. Critically analyzing the sampled newspapers separately, we can make out the priorities and, can draw the inferences between the English and Urdu newspapers. Firstly, The Jang newspaper, a total of 271 development news was published in the sampled months of November and December 2018. On analyzing the above mention data it is obvious that the Urdu sampled newspaper The Jung has given very little place to development news on his first page (approximately $4.5 \%$ of total development news).

Table 5: Placement of News in Daily Jang

\begin{tabular}{lccc}
\hline & Front Page & Inner Pages & Back Pages \\
\hline Education & & 25 & 15 \\
Health & 5 & 13 & 7 \\
Economic & & 26 & 14 \\
Environment & & 5 & 3 \\
Women empowerment & 1 & 6 & 1 \\
Children rights & 3 & 34 & 23 \\
Infrastructure & & & \\
\hline
\end{tabular}




\begin{tabular}{lccc}
\hline Agriculture & & 4 & 3 \\
Energy & 3 & 19 & 9 \\
Industrial development & & 5 & 1 \\
Misc. /others & & 30 & 15 \\
G. Total & 12 & 168 & 91 \\
\hline
\end{tabular}

From Table 5 it can be found that Daily that most development news was published in the middle pages of Daily Jang (168) and the least number of stories were published on front pages (12). The majority of the news appeared in the category of infrastructure and these also appeared in the middle pages of the newspaper.

Table 6: Placement of News in Daily Dawn

\begin{tabular}{lccc}
\hline \multicolumn{1}{c}{ Category } & Front Pages & Inner Pages & Back Pages \\
\hline Education & & 14 & 23 \\
Health & & 20 & 18 \\
Economic & & 24 & 23 \\
Environment & & 10 & 13 \\
Women empowerment & & 12 & 11 \\
Children rights & 2 & 3 & \\
Infrastructure & & 26 & 27 \\
Agriculture & & 11 & 2 \\
Energy & 1 & 12 & 9 \\
Industrial development & 1 & 17 & \\
Misc. /others & 4 & 156 & 24 \\
G. Total & & 150 \\
\hline
\end{tabular}

The results from Table 6 elaborate that on the front pages of Daily Dawn only four news stories were published. While in inner pages 156 stories were published and the last page contributed to 150 stories. Most of the stories in inner pages (156) and last pages (150) were about infrastructure.

Table 7: Overall Pictorial Presentation of the News in the Newspapers

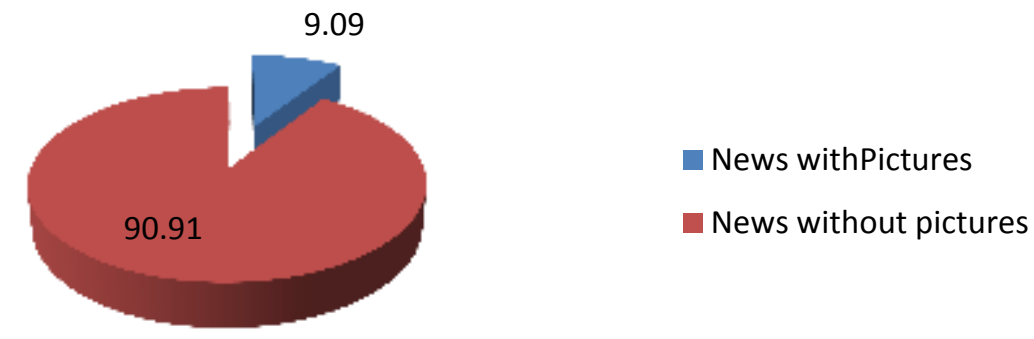

According to the above chart, it can found that only $9.09 \%$ of news was accompanied by pictures while the rest of the news published was without any picture.

Table 8: Category wise Pictorial Presentation of the News in the Newspapers

\begin{tabular}{lcc}
\hline \multicolumn{1}{c}{ Newspaper } & News Published & News Published with Pictures \\
\hline Daily Jang & 271 & $\mathbf{1 4}(5.16 \%)$ \\
Daily Dawn & 301 & $\mathbf{3 8}(\mathbf{1 1 . 8 3 \% )})$ \\
Total & $\mathbf{5 7 2}$ & $\mathbf{5 2}(\mathbf{9 . 0 9 \% )}$ \\
\hline
\end{tabular}

According to the above table in Daily Jang out of 271 publications, only 14 publications were accompanied by pictures whereas the remaining 257 publications are without any picture. Similarly, Daily Dawn newspaper published 301 stories about development in the sampled months i.e. November and December 2018, only 38 publications are with pictures whereas the remaining 263 publications are without pictures. On comparing both newspapers it is observed that Daily Dawn news publication has more pictures than Daily Jang newspaper however both the newspapers published the stories with pictures in the particular field of infrastructure, economics and educations. This trend of publishing the stories with pictures also indicates the readers' interest and their area of influence as well. Pictorial presentations of the issues indicate how much the issues are given due attention to and more significance than those without pictorial presentations. 


\section{Answers to Research Questions}

This study was aimed to investigate the coverage of development news in two leading newspapers of the country i.e. Daily Dawn and Daily Jang. The study was carried out keeping under consideration the following research questions.

1. What was the extent of coverage provided to different categories of development news by the sample newspapers?

2. Which newspaper provided more coverage to development news overall?

3. What was the placement of development news on different pages of the newspapers?

4. How many news items were accompanied by pictorial image?

After detailed content analysis following answers were found to research questions posed:

Q1. What was the extent of coverage provided to different categories of development news by the sample newspapers?

Results from Table indicate that the Infrastructure category of development published most frequently $(20.09 \%)$ in the newspapers. At the second number Economic category's news was published (16\%).Miscellaneous/other categories' news got published with the ranking of third number (15.2\%). Development category which stood fourth in frequency of publication is that of Education $(13.5 \%)$. The other categories published as health (13.5\%), environment (3.5\%), women empowerment (5\%), children rights (1\%), agriculture (3.49\%), Energy (9\%), and industrial development $(2.62 \%)$

\section{Q.2 Which newspaper provided more coverage to development news overall?}

According to Table 2, Daily Jang published 271 news stories on different pages of the newspaper, and Daily Dawn published 301 news stories overall during the period of research. Hence, it can be concluded development news got more coverage in the English newspaper than the Urdu newspaper of Daily Jang.

\section{Q.3 What was the placement of development news on different pages of the newspapers?}

Table very clearly elaborates placement of different categories of development news on front, back, and inner pages of sample newspapers. According to results most of the news was published in inner pages of the newspapers $(55.77 \%)$ while last pages $(41.48 \%)$ were published. The least number of news $(2.75 \%)$ was published on the front pages of sample newspapers. Tables 5 and 6 also describe the placement of news in Daily Jang and Daily dawn separately. According to the results Daily Jang published 12 news on front pages, 168 news on inner pages, and 91 news on the last pages of the newspaper. On the other hand, Daily Dawn published only 4 stories on front pages, 156 stories on inner pages, and 150 stories on back pages. Overall it can be observed that both Urdu and English newspapers published the least number of stories on their front pages.

\section{Q.4 How many news items were accompanied by a pictorial image?}

After data analysis of news with the pictorial image, it was revealed in Table 7 that overall only $9.09 \%$ of the news stories were having image/picture along with them while the remaining $91 \%$ stories were having no image. Table 8 further elaborates a comparison of English and Urdu newspapers namely Daily Dawn and Daily Jang. Results indicate that in Daily Jang $5.16 \%$ news stories were accompanied by images and in Daily Dawn $11.83 \%$ news stories carried image along with the news. Here, it is again shown that the English newspaper; Daily Dawn was having more news with images than that of Daily Jang.

\section{Findings}

Findings of this research the following important points.

1. While analyzing coverage of different categories of development news it was found that the infrastructure category of news was published in a greater number as compared with the categories of development.

2. Results also elaborate that English news media; Daily Dawn provided more coverage to development news than Urdu media; Daily Jang.

3. It was found that the least number of development news was published on the front pages of sample newspapers.

4. According to results, it was found that newspapers were least bothering to publish development news along with the pictorial display. 
5. Results from table 2 also reveal that English news medium; Daily Dawn dedicated more average space (337.7centimeter) than Daily Jang (170.2 centimeter). It means that the English

\section{Conclusion} press provides more coverage to development issues than the Urdu press.

This research was designed primarily to explore the coverage of development news in leading newspapers of Pakistan both English and Urdu. Findings of research indicate that there is not enough coverage of development news in the Pakistani press. When the trend of coverage was analyzed it was revealed that newspapers are flooded with infrastructure news- all news which is describing and portraying development projects undertaken by the different governments. Overall in third world countries, the tool of development journalism is used by different governments to gain the attention of masses. It is saddening to note that health, education, women rights, and children issues are gaining very little coverage concerning frequency and space. It is observed that the English press is more focused on development news than the Urdu press and hence coverage is more than do the Urdu press. Another important point of concern is that both Urdu and English press are not providing proportionate coverage to development news on their front pages and hence most of the news is appearing on last and inner pages.

\section{Recommendations}

During the whole course of the research, it was realized that there is dire need to provide proper space and coverage to development news in the Pakistani press. The following are a few recommendations for future researchers.

1. There is a great margin of conducting research on development issues in electronic media; especially in TV news channels.

2. It is suggested to research factors that account for publication and stoppage of development news in media.

3. Role of Social Media in creating awareness about development issues is an interesting area to work on.

\section{References}

George, S. (2009). What is development journalism? The Guardian. Retrieved on November $6^{\text {th }}$, 2017, from http://www.theguardian .com/journalism competition /pro fessio nal-what-isdevelopment journalism

Hujanen, J. (2013). Use of development dialogues in learning and changing journalism practice. Nordicom Review. 34(2): 93-106.

Hussain, T. \& Shabir, G. (2019). Treatment of Developmental Journalism in Pakistani and Indian Press: A Comparative Study of Daily Dawn, Times of India, Jung and Daily Sahafat. Global Regional Review. Vol. IV, No. IV. Page: 238 - 248.

Hussain, T. (2017). Developmental Journalism in Pakistani and Indian Press. (Unpublished Ph.D. Thesis), the Islamia University of Bahawalpur.

Kelleher, C. D. (2014). A consideration of development journalism in the context of Rwandan newspapers. (Unpublished Master's Thesis), The University of Texas, Austin.

McDaniel, D. (1986). Development News in Two Asian Nations. Journalism Quarterly, 63(1), 167170 .

Oladele, O. I. (2009). Innovative Approaches for Improving Access to Agricultural Information: Cases, Applications, and Role of Media. CTA Annual Seminar Report. Brussels, Belgium

Perrottet, A. J. D. (2015). News values in the pacific nations: A case study in development journalism and the reporting of the pacific islands furam in Fijji, Vanuatu, and New Zealand. (Unpublished Master's Thesis), School of communication, University of Technology, Aukland

Shah, H. (1990). Factors influencing development news production at three Indian dailies. Journalism Quarterly, Vol. 67 (4): 1034-1041.

Singhal, A. \& Rogers, E. M. (2001). Indian's Communication Revolution: From Bullock Carts to Cyber Marts. Sage: New Delhi. 